\title{
Persica qeshmensis gen. nov. sp. nov from the Persian Gulf (Platyhelminthes: Polycladida: Acotylea), with remarks on reproductive structures
}

\author{
Abdolvahab Maghsoudlou $^{\mathrm{a}, \mathrm{b} *}$, Veronica N. Bulnes ${ }^{\mathrm{c} *}$ and Hassan Rahimian ${ }^{\mathrm{a}}$ \\ ${ }^{a}$ School of Biology and Centre of Excellence in Phylogeny of Living Organisms, College of \\ Science, University of Tehran, Tehran, Iran; ${ }^{b}$ Iranian National Institute for Oceanography and \\ Atmospheric Science (INIOAS), Tehran, Iran; ${ }^{c}$ Zoología de Invertebrados I, Departamento de \\ Biología, Bioquímica y Farmacia, Universidad Nacional del Sur, Bahía Blanca, Argentina
}

(Received 29 March 2013; accepted 7 January 2015; first published online 24 February 2015)

\begin{abstract}
A new genus of acotylean polyclad, Persica qeshmensis gen. nov. sp. nov. (Acotylea, Pleioplanidae), was collected from intertidal rocky shores of the Northern Persian Gulf, Iran. The genus Persica is established on the presence of small tentacles; tentacular and cerebral eyes; spermiducal bulbs; true seminal vesicle; prostatic vesicle of atomata-type; muscular coiled ejaculatory duct, provided with a stylet, absence of a vagina bulbosa or Lang's vesicle. Persica qeshmensis is characterised by a sandy beige to light brown background colour, with pale brown microdots, light grey ventral body surface, coiled ejaculatory duct embedded in parenchymatous cell mass, elongated sigmoid stylet, a well-developed penis sheath located in a small male atrium, and with a non-muscular blind chamber extending anteriad from the vagina to the level of the genital sucker.
\end{abstract}

http://zoobank.org/urn:1sid:zoobank.org:pub:FAA7AA0A-6954-47D0-A5B2$1 \mathrm{~A} 2 \mathrm{EC} 04050 \mathrm{C} 3$

Keywords: polyclads; Pleioplanidae; taxonomy; Persian Gulf; Qeshm Island

\section{Introduction}

For polyclads, two classification systems coexist (Faubel 1983, 1984; Prudhoe 1985) that are not fully concordant, thus sometimes resulting in taxonomic conflicts when it comes to the systematic placement of new species. These discrepancies also have a negative effect on other aspects of biodiversity studies on polyclads (Gammoudi et al. 2009).

A major difference between these two systems is that Faubel $(1983,1984)$ attempted to provide a classification based on a Hennigian phylogenetic analysis. In his study, he considered the inner lining of the prostatic vesicle as a character of apomorphic importance in several families, such as Cryptocelididae, Gnesiocerotidae, Notoplanidae and Pleioplanidae. Bulnes (2010) made extensive remarks on these structures when she described the new genus Izmira Bulnes 2010 for the family Pleioplanidae.

This family Pleioplanidae is characterised by the presence of an atomata-type of prostatic vesicle. In this case, the inner glandular lining develops tubular chambers growing from the proximal end, directed backwards and filling almost the whole lumen of the vesicle (cf. Bulnes 2010, fig. 9D). These chambers are oriented parallel to the ejaculatory duct and directed distally to the end of the vesicle. The number of

*Corresponding authors. Emails: wahabbio@gmail.com; vebulnes@criba.edu.ar 
tubular chambers appears to be constant within the Pleioplanidae, which gives to this character a diagnostic value for this family (Bulnes 2010).

The present paper describes a new species of pleoplanid polyclad, which also possesses the atomata-type of prostatic vesicle, from the shallow rocky bottoms of the Persian Gulf.

In addition, we provide an identification key to the genera of the family Pleioplanidae.

\section{Material and methods}

Sampling was carried out during three field trips (November 2010, February and March 2011) at five localities along the intertidal zone of the Iranian coast $\left(24^{\circ}-\right.$ $\left.30^{\circ} 30^{\prime} \mathrm{N}, 48^{\circ}-56^{\circ} 25^{\prime} \mathrm{E}\right)$ of the Persian Gulf, connected to the Indian Ocean through Hormoz strait and Makoran (Oman) sea from the east (Figure 1; Table 1). The sampling effort at each location was based on $4.5 \mathrm{~h}$ search per day, during low tide, along a stretch of $1 \mathrm{~km}$ parallel to the shore (50-150 $\mathrm{m}$ in width).

Fifteen specimens were collected and fixed after a modified protocol from Newman and Cannon (1995): individuals were coaxed onto a filter paper and placed into frozen $10 \%$ buffered formalin with seawater and transferred to $70 \%$ ethanol for long-term preservation. Five specimens were selected for histological examination; their posterior parts were dissected, embedded in paraffin, sagittally sectioned $(7 \mu \mathrm{m})$ and stained with Mayer's haematoxylin and eosin for histological examination under a compound microscope (Leica DM 500) and stereo-zoom microscope (Nikon SMZ 1500). Two of the 15 specimens (Table 1) were fixed in modified Carnoy's fixative (6 parts 100\% ethyl alcohol, 3 parts chloroform, 1 part glacial acetic acid), rehydrated, stained in Carmalum, dehydrated, cleared in xylene) and finally whole mounted with synthetic Canada balsam (Gertraud 1999). The remaining eight specimens were preserved in ethanol 70\% (Table 1).



Figure 1. Geographical positions of the sampling localities along the northern Persian Gulf. 1, Salakh; 2, Toula; 3, Baghestan; 4, Charak-Aftab; 5, Chahak. 


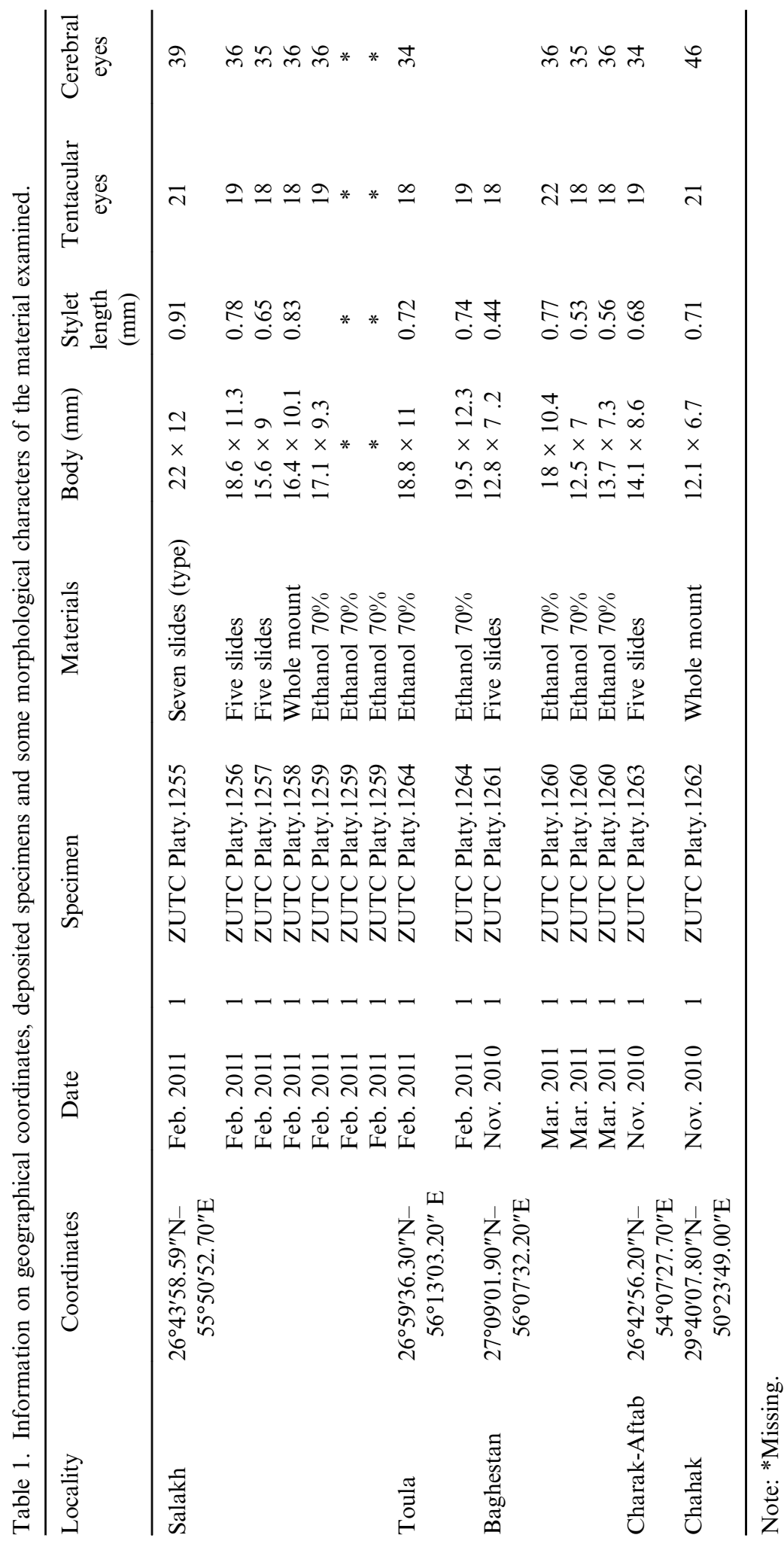


Diagrammatic reconstructions of the reproductive system were based on serial sections and whole mounts and were prepared with the aid of a camera lucida mounted on a compound microscope (Richert Biovar). Taxonomic identifications were based on the classification systems of Faubel (1983, 1984). Specimens are deposited at the Zoological Museum, University of Tehran Collection, Iran (ZUTC).

Information on each location, collected specimens and museum catalogue numbers is provided in Table 1. Single measurements in descriptions are those of the fixed holotype, unless stated otherwise.

\section{Systematic account}

\section{Leptoplanoidea Faubel, 1984 \\ Pleioplanidae Faubel, 1983}

\section{Diagnosis}

Leptoplanoidea with varying outline of the body. Ruffled pharynx arranged centrally or somewhat anterior. Male copulatory apparatus directed backwards, behind pharynx. True prostatic vesicle of Notoplana type present; its glandular lining epithelium is subdivided into a great number of elongate tubular chambers (atomata type).

Key to genera (modified from Bulnes 2010)

1. Male copulatory apparatus with penis stylet .................................................. 2



2. Lang's vesicle present Pleioplana Faubel, 1983

- Lang's vesicle lacking Persica gen. nov.

3. Lang's vesicle present Melloplana Faubel, 1983

- Lang's vesicle lacking Izmira Bulnes, 2010

Genus Persica gen. nov.

\section{Diagnosis}

Pleioplanidae with oval body shape. Tentacular and cerebral eye-spots present; tentacles small. Male copulatory apparatus with spermiducal bulbs and true seminal vesicle; prostatic vesicle of atomata-type; muscularised elongated ejaculatory duct, provided with a stylet. Without vagina bulbosa or Lang's vesicle.

Type species

Persica qeshmensis sp. nov.

\section{Etymology}

The generic epithet derives from the latinisation of the Greek name of Persia (Пєрбıки́), gender female. 
A



C

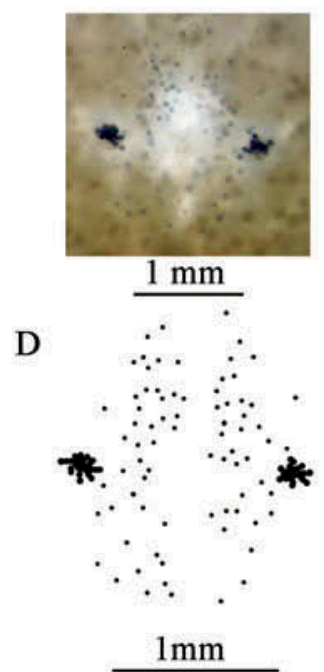

B

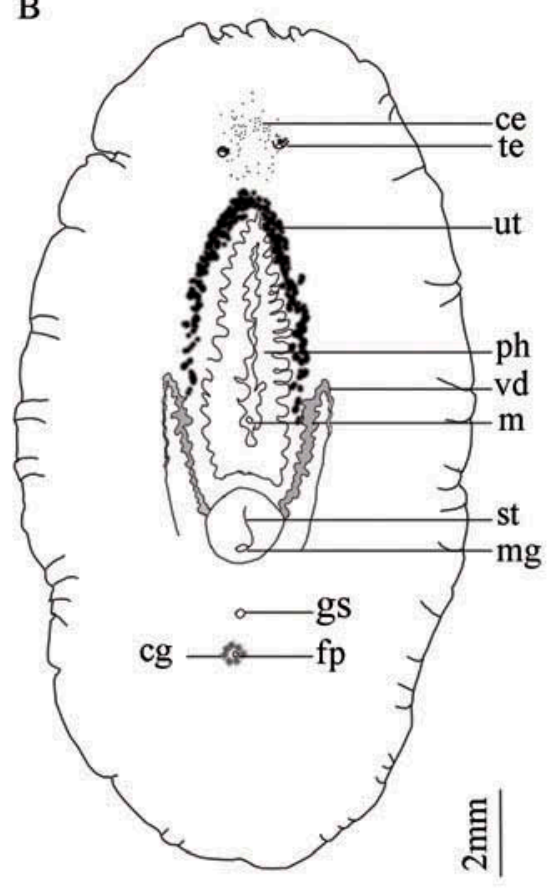

E

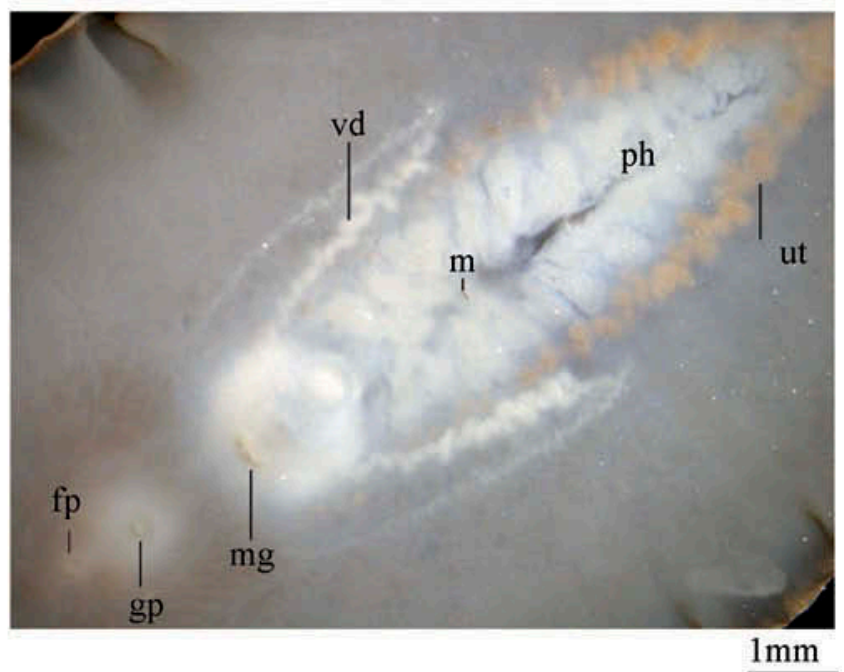

Figure 2. Persica qeshmensis (ZUTC Platy.1255): (A) dorsal view; (B) diagram of whole specimen; (C) dorsal view of cerebral region; (D) diagram of tentacular and cerebral eyes; (E) ventral view. Abbreviations: ce, cerebral eyes; cg, cement glands; fp, female pore; gs, genital sucker; m, mouth; mg, male gonopore; ph, pharynx; st, stylet; te, tentacular eyes; ut, uterus; vd, vas deferens. 
A

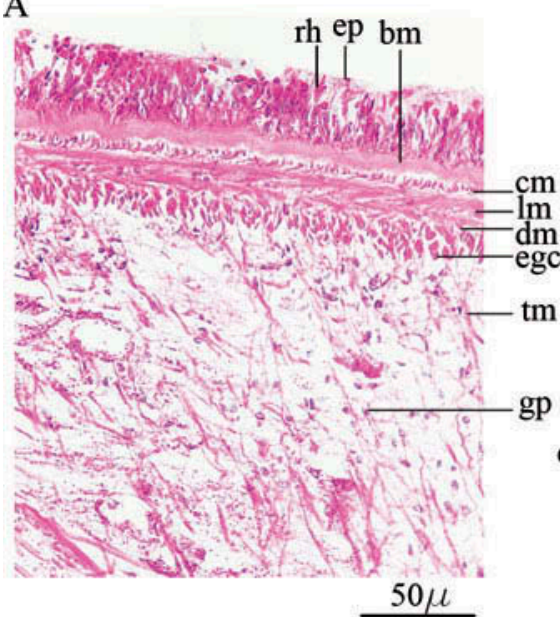

B



Figure 3. Persica qeshmensis. (A) Sagitally sectioned dorsal epidermis; (B) sagitally sectioned ventral epidermis. Abbreviations: bm, basement membrane; $\mathrm{cm}$, circular muscles; dm, diagonal muscles; egc, eosinophilic glandular clusters; ep, ciliated epidermis; gp, granular pigment; lm, longitudinal muscles; rh, rhabdites; tm, transverse muscles.

\section{Persica qeshmensis sp. nov.}

(Figures 2-6, 7A-C)

\section{Diagnosis}

Background colour of the dorsal surface sandy beige to light brown, with pale brown microdots; ventrally light grey; coiled ejaculatory duct immersed in a parenchymatous cell mass; elongate sigmoid stylet, and well developed penis sheath situated in a small male atrium; a non-muscular blind chamber bulging anteriorly from the distal vagina; well-developed genital sucker between male and female gonopore.

\section{Material examined}

Holotype: Seven slides of posterior end as sagittal serial sections, ZUTC Platy.1255.

Paratypes: Posterior ends of three specimens in serial sagittal sections, two specimens mounted whole, and eight specimens preserved in $70 \%$ ethanol. For further details, see Table 1.

Figure 4. Persica qeshmensis. (A) Microphotograph of sagittal section of male reproductive complex; (B) sagittal reconstruction of the reproductive system; (C) microphotographic detail (sagittal section) of stylet and male atrium; (D) microphotographic detail (sagittal section) of prostatic extra-vesicular glands. Abbreviations: ej, ejaculatory duct; exc, extra-vesicular gland's channel; exg, extra-vesicular glands; i, intestine; ma, male atrium; mg, male gonopore; ps, penis sheath; pt, parenchymatous tissue; pv, prostatic vesicle; s, stylet; sb, spermiducal bulb; sv, seminal vesicle; tc, tubular chamber. 


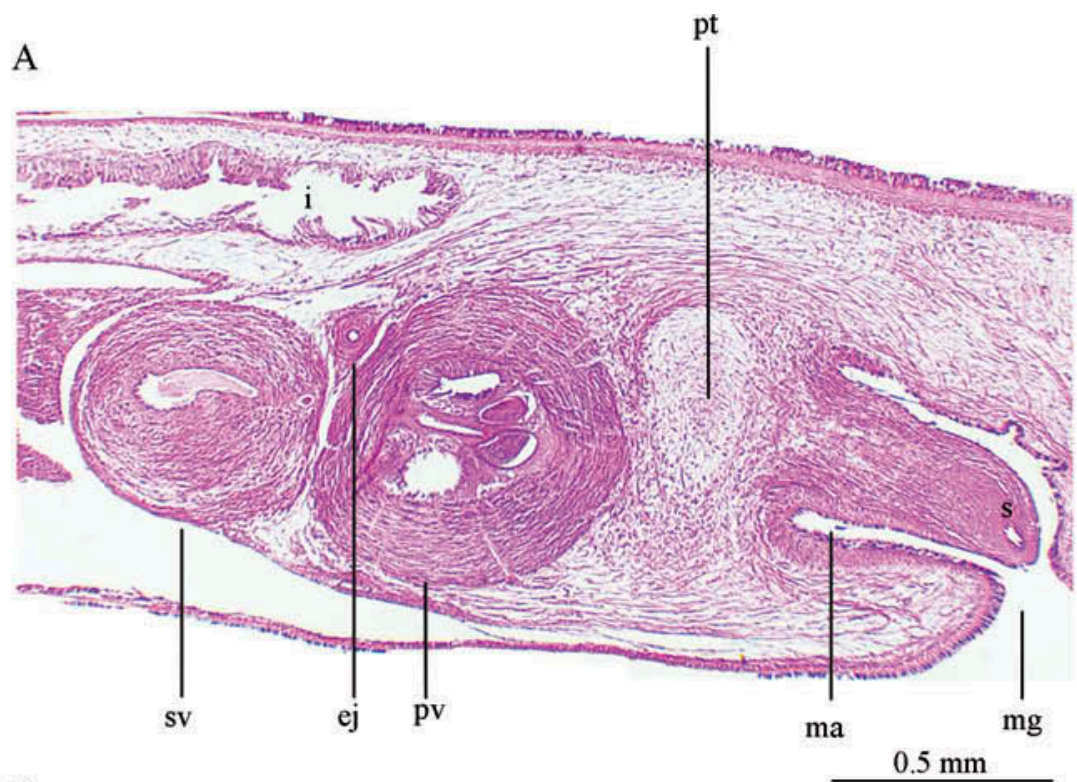

B

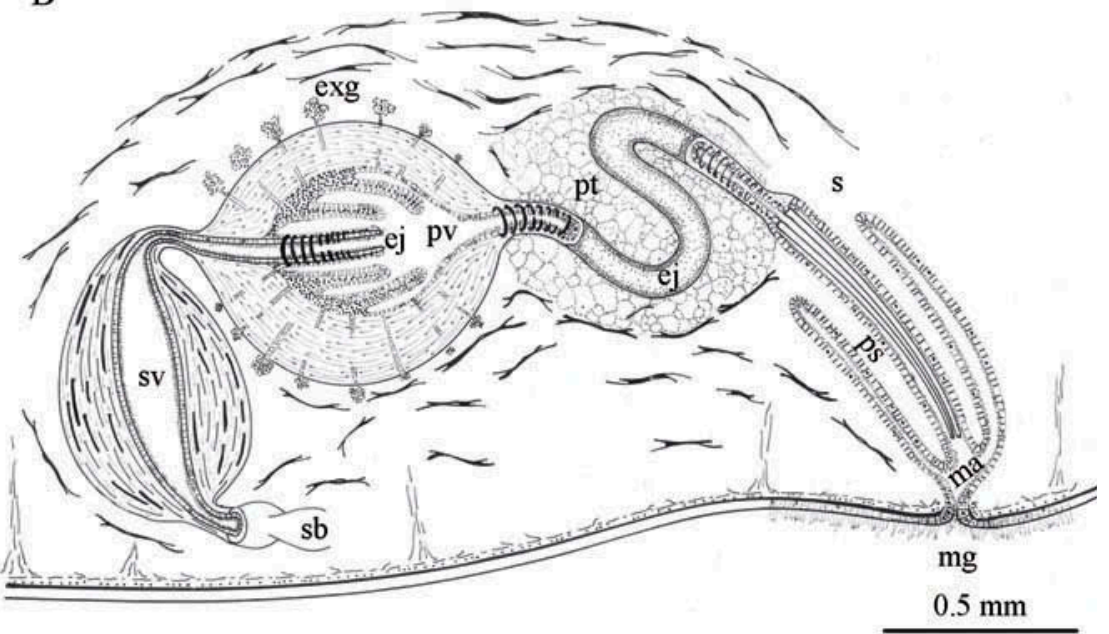

C
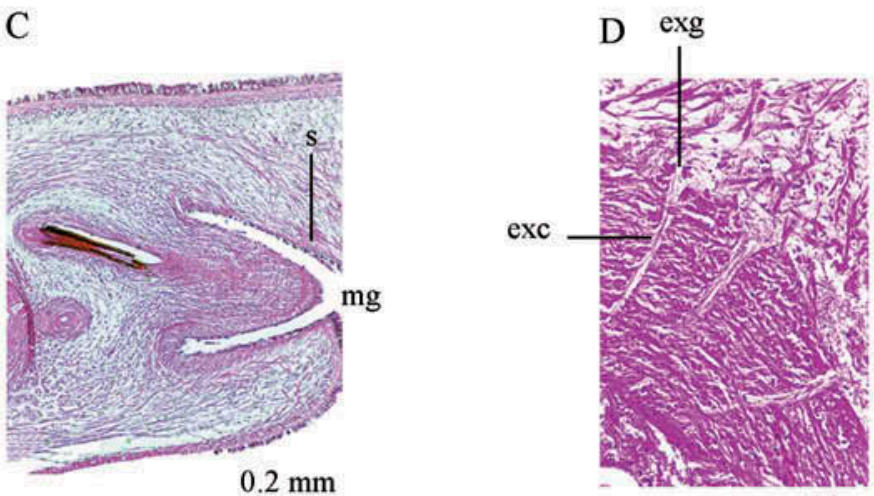


\section{A. Maghsoudlou et al.}

A

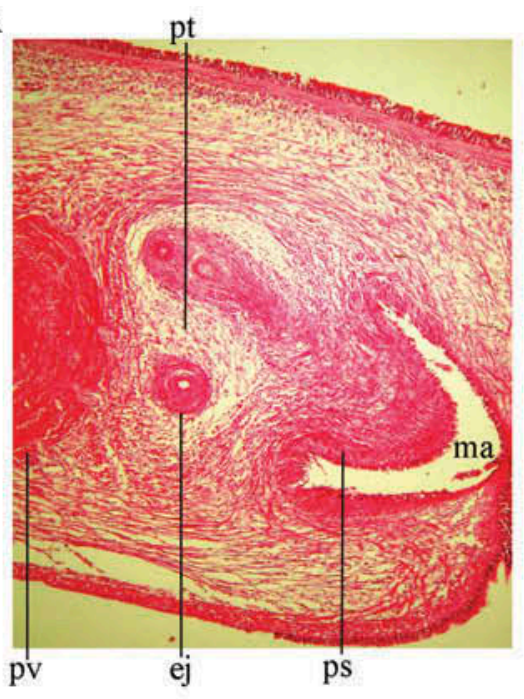

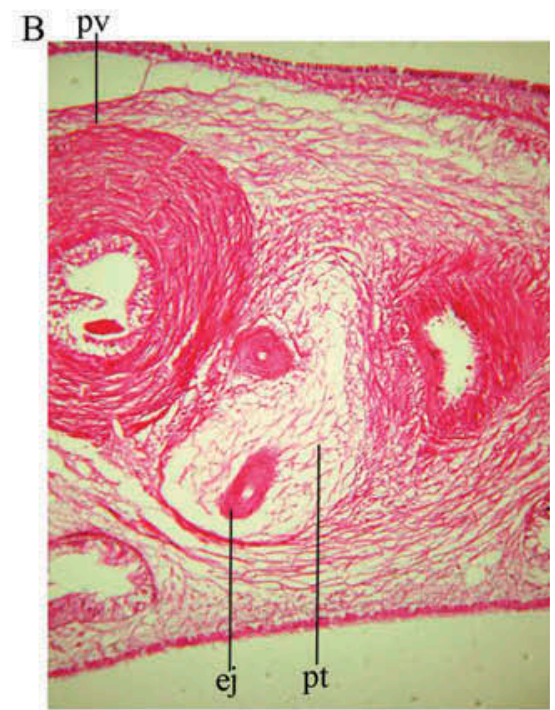

C

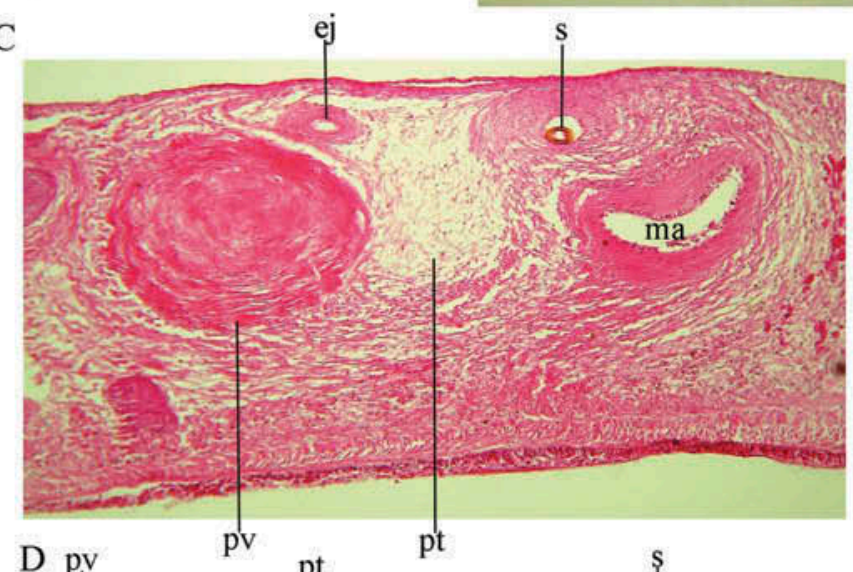

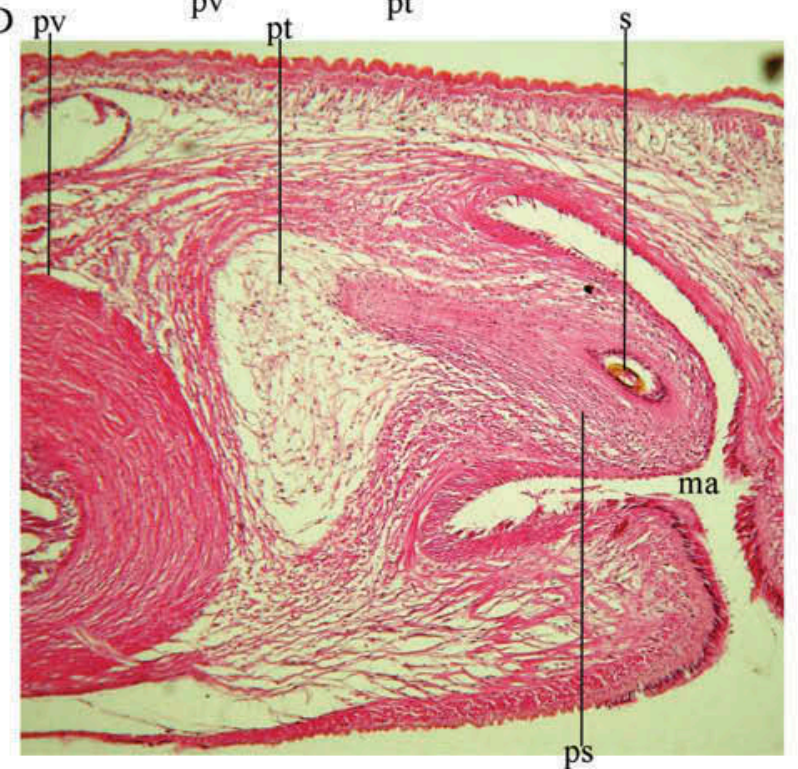


Etymology:

The specific epithet alludes to the type locality, Qeshm Island, in the Persian Gulf.

\section{Description \\ External morphology}

Body broadly oval, soft and translucent. Dorsal ground colour sandy beige to light brown, darker around the pharynx, with pale brown microdots, except over the pharynx and towards the body margin (Figure 2A). Ventrally light grey to whitish. Fixed specimen $22 \mathrm{~mm}$ long, $12 \mathrm{~mm}$ wide (Figure 2A-B). Small nuchal tentacles present. Tentacular eyes more crowded at the base of tentacles, each cluster with about 20 eye-spots. Cerebral eyes smaller, in two clusters behind the brain, each with about 39 eye-spots (Figure 2C). Marginal eyes absent (Figure 2B-D).

\section{Digestive system}

Ruffled pharynx located centrally, with about 13 lateral folds, $7 \mathrm{~mm}$ in length (one third of the body length), mouth in posterior third of the pharyngeal cavity, opening to main intestine anteriorly to the male apparatus (Figure 2E).

\section{Body wall}

Dorsally $72 \mu \mathrm{m}$ high. Cellular ciliated epidermis with columnar cells, rhabdites apparent, basement membrane $11 \mu \mathrm{m}$ high. Three distinct subepidermal muscle layers: an outer circular, middle longitudinal and inner diagonal. Transversal muscle fibres well developed. Eosinophilic gland cells present beneath the muscular layers (Figure 3A).

Ventral body wall $85 \mu \mathrm{m}$ high, thicker between gonopores, where the genital sucker is located (130-140 $\mu \mathrm{m}$ high). Cellular epidermis sparsely provided with rhabdites, basement membrane $6 \mu \mathrm{m}$ high. Subepidermal outer circular muscle layer is followed inwards by a thinner layer of longitudinal muscles and a welldeveloped diagonal muscle layer interspersed with circular fibres (Figure 3B). Large eosinophilic glandular cells between male gonopore and genital sucker. Smaller basophilic cells extend from this point posteriorly towards the female system, merging with cement glands. Scattered granular pigment cells between ventral and dorsal muscle fibres as well as in the parenchyma (Figure 3A-B).

\section{Male copulatory complex}

Male apparatus directed backwards, with true seminal vesicle, interpolated tubular prostatic vesicle and elongated stylet (Figure 4A-B). Testes ventral and located toward the margin along the whole body. Vasa deferentia extend forwards up to

Figure 5. Persica qeshmensis. Sagittal sections of male copulatory organ; (A) ZUTC Platy. 1255 (ype); (B) ZUTC Platy.1256; (C) ZUTC Platy.1263; (D) ZUTC Platy.1257. Abbreviations: ej, ejaculatory duct; ma, male atrium; ps, penis sheath; pt, parenchymatic tissue; pv, prostatic vesicle; s, stylet. 
A

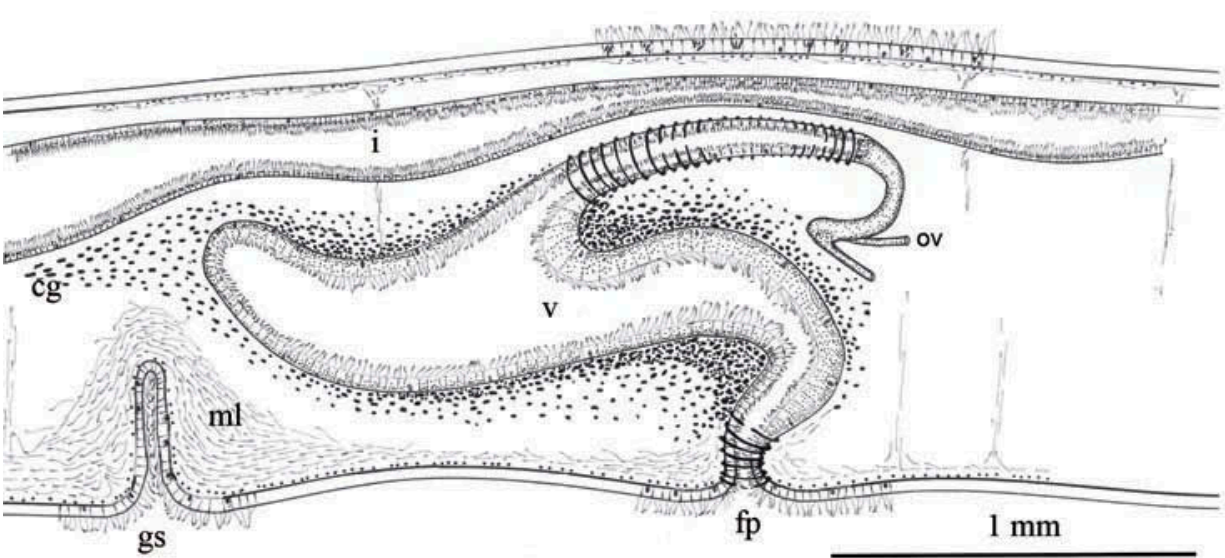

B

C
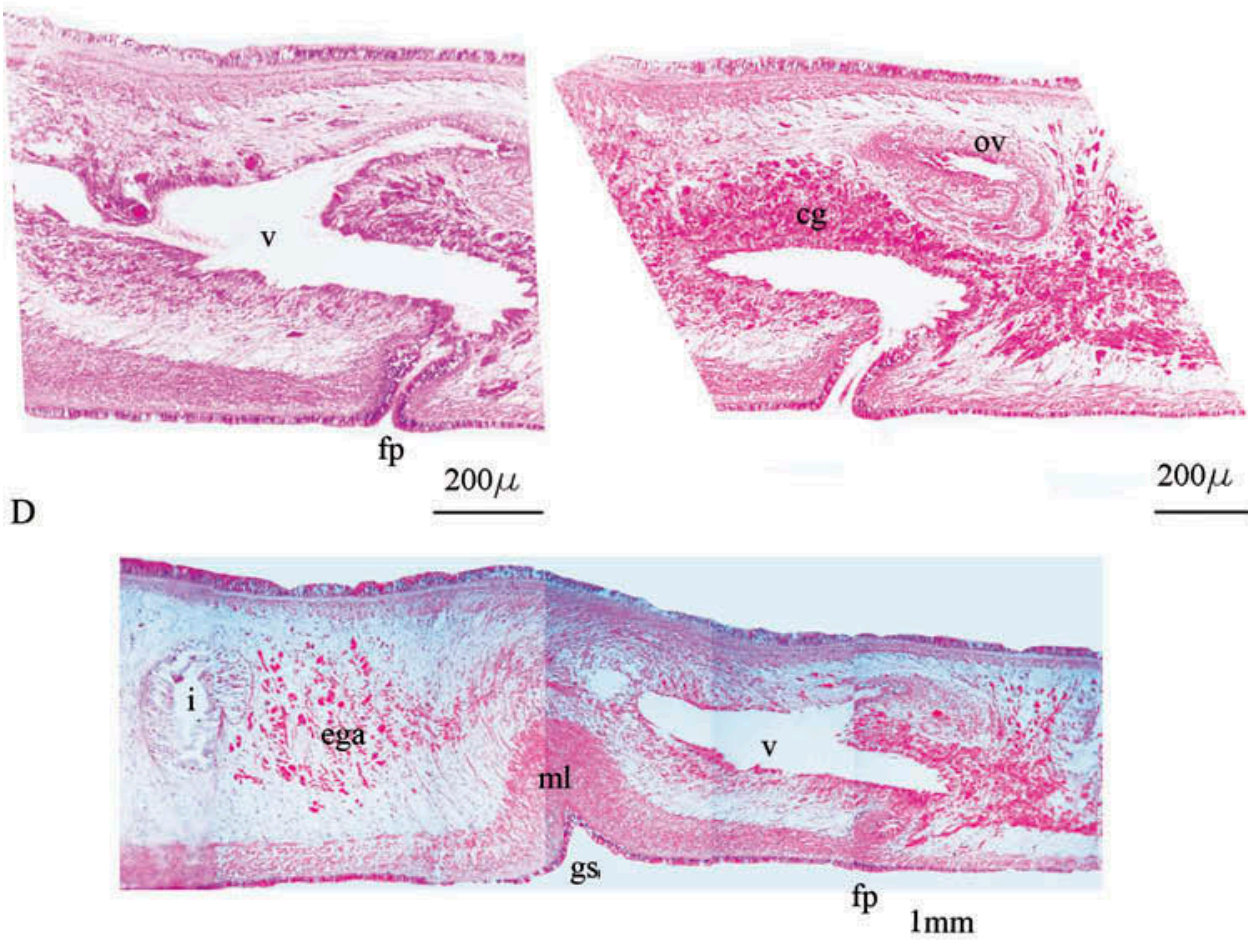

Figure 6. Persica qeshmensis. (A) Sagittal reconstruction of the female reproductive system; (B) microphotograph (sagittal section) of vagina and female gonopore; (C) microphotograph (sagittal sections) of vagina and oviduct; (D) microphotograph (sagittal section) of genital sucker and female reproductive system. Abbreviations: cg, cement glands; ega, eosinophilic glandular area; fp, female pore; gs, genital sucker; i, intestine; ml, muscular layer; ov, oviduct; $\mathrm{v}$, vagina. 
the mouth and then recurve, forming (Figure 2E) spermiducal bulbs, shortly before entering the seminal vesicle from the posterior side (Figure 4B). Seminal vesicle located immediately behind the pharynx, spherical, $520 \mu \mathrm{m}$ in diameter and occupying more than half of body width. Its muscular wall is highly developed (Figure 4A-B). The rounded interpolated prostatic vesicle measures about $650 \times 640 \mu \mathrm{m}$ and is surrounded by a strongly developed muscular wall (Figure 4A-C). Glandular epithelium of the prostatic vesicle tubular and divided into four chambers, while numerous extra-vesicular glands discharge their secretion into the lumen (Figure 4B, D). The ejaculatory duct projects into the prostatic vesicle and is not immediately attached to the glandular lining. The ejaculatory duct possesses a well-defined muscular wall. Between the prostatic vesicle and the stylet, there is a mass of specialised parenchymatous tissue, $(440 \times 280 \mu \mathrm{m})$, where the highly muscularised ejaculatory duct bends before entering the stylet. This parenchymatous tissue consists of large, loosely arranged vacuolated cells, with thin cell walls and a scattered intercellular matrix, limited by scattered muscle fibres (Figures 4A, 5A-D). The elongated, sigmoid stylet (910 $\mu \mathrm{m}$ long) is housed in an elongated penis sheath and a small male atrium (Figures 2B, 5D). The seminal vesicle, prostatic vesicle, specialised parenchymatous tissue, ejaculatory duct and penis sheath are surrounded by concentric longitudinal muscle fibres, albeit these do not form a distinct bulb (Figure 4B). In resting position, when the stylet lies in the male atrium, the male copulatory complex is not aligned with the main longitudinal body axis, but is coiled (Figure 4B).

\section{Female system}

Ovaries dorsal. Uteri well developed anterior to mouth (Figure 2B, E), giving rise to narrow paired oviducts, which open into the vagina at its ventral side. From this point, the vagina turns dorsally and runs anteriorly, then turns ventrally to the gonopore (Figure 6A). Proximal part of the female genital canal slender, with cuboidal ciliated epithelium, surrounded by a well-developed muscular wall. Distally, the vaginal tract is surrounded by an adjacent mass of glandular cells. The vagina is lined with cylindrical secretory and ciliated cells. A blind vaginal chamber extends forwards. The wall of this chamber possesses the same structure as the distal tract of the vagina (Figure 6A-D). Gonopores separated $(2.3 \mathrm{~mm})$, located in the posterior third at last third of the body (Figure 2B, E). Well-developed genital sucker between gonopores, $0.2 \mathrm{~mm}$ deep (Figure 6A, D).

The size of the collected specimens ranged between $12.1 \times 6.7 \mathrm{~mm}$ and $22 \times 12 \mathrm{~mm}$ (Table 1). In concordance with this variability, bigger animals develop more eye-spots and some variability in the body outline and size (Figure 7A-C). Nevertheless, the anatomy of all examined specimens reveals a great uniformity. The position of the mouth, the presence of apparent spermiducal bulb, the presence of a genital sucker, the highly muscularised male copulatory complex, the long and slender stylet and the characteristic morphology of the female system leave no doubt as to species identity. For these reasons, we found Faubel's system more suitable for the determination of this new species. 
1488 A. Maghsoudlou et al.
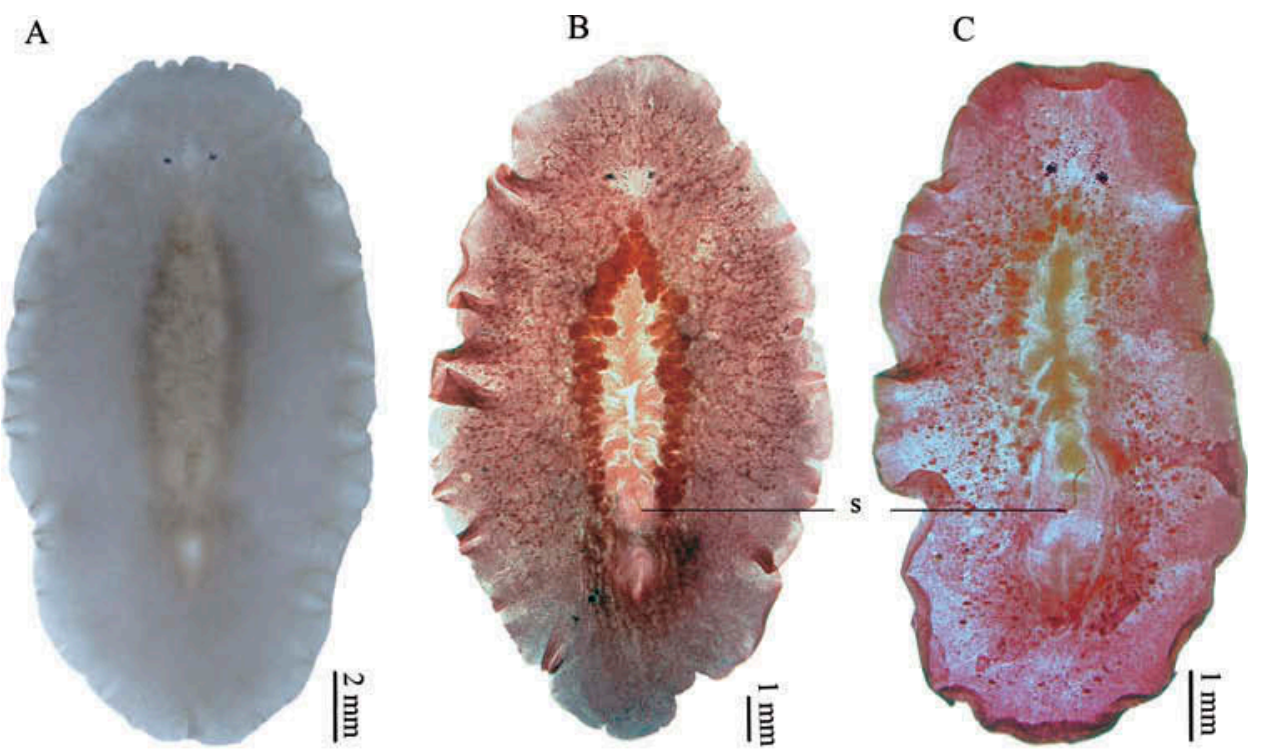

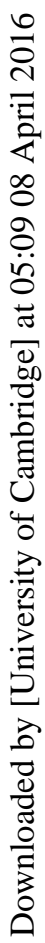
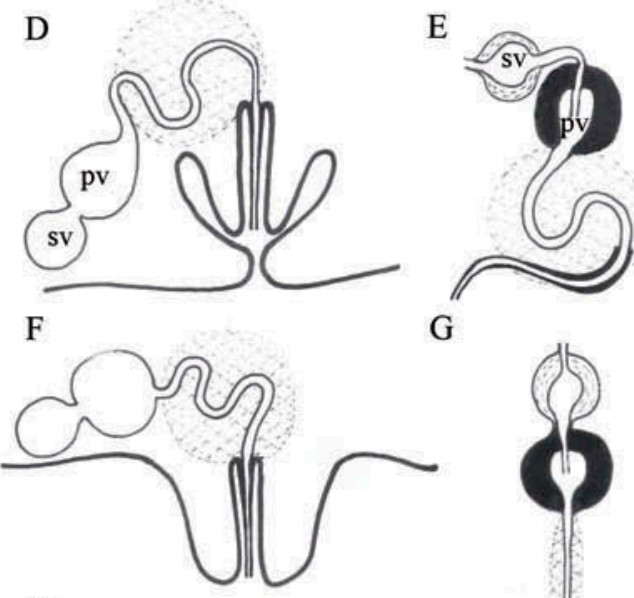

H
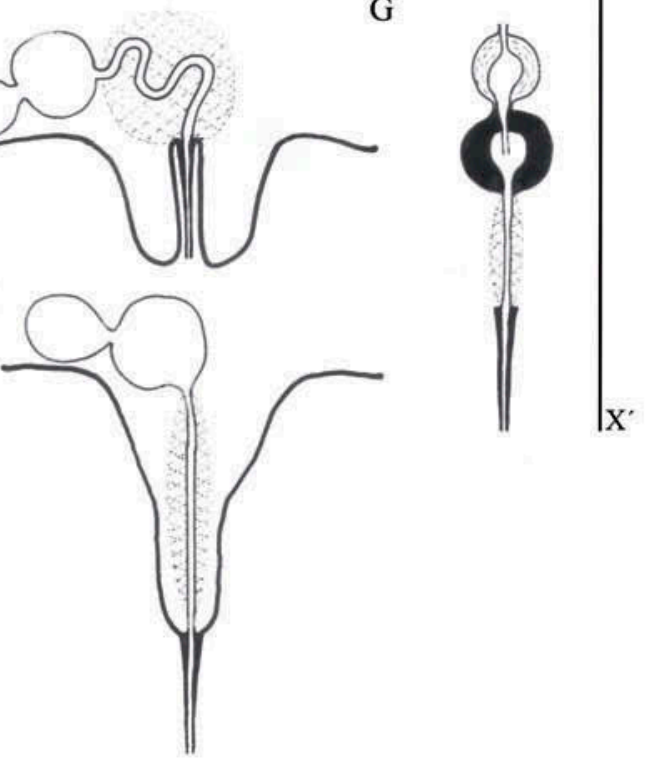


\section{Discussion}

Within the acotyleans, the presence of a genital sucker has been reported only for a few species from different genera. The acotylea genital sucker is a glandular structure located between the male and female gonopores, but never behind them as in the cotyleans (Faubel 1983, p. 85). The presence of a genital sucker is not consistent within different genera; thus, this character will be still considered of specific level. Although some other important differences at the generic level are present, Persica qeshmensis shares the presence of a genital sucker with Leptoplana tremellaris Müller O.F, 1774, Itannia ornata Marcus, 1947, Cestoplanides lactea (Kato, 1937), and some members of the genus Cestoplana Lang, 1884. The genus Leptoplana is characterised by the presence of a prostatic vesicle with poorly differentiated glandular lining and an eversible unarmed cirrus. Itannia has a prostatic vesicle with a poorly developed glandular lining and two genital suckers besides the female gonopore, Cestoplanides is characterised by the presence of multiple male copulatory organs and Cestoplana possesses a prostatic vesicle with smooth glandular lining and a sucker in the hindmost end of the body. Persica quesmensis has an interpolated prostatic vesicle with tubular chambered inner glandular lining, and a single male copulatory organ armed with a penis stylet.

In 1983, Faubel described the bursa copulatrix as a blind muscular chamber which sets off from the vaginal wall, and considered the presence of this structure to be of generic level. Persica qeshmensis possesses a blind chamber connected to the vagina, but its inner lining does not differ from the vagina's inner lining; thus, we do not consider this to be a bursa copulatrix, and we include this feature in the diagnosis of the species.

The presence of a loose parenchymatous tissue associated with the male copulatory organ of $P$. qeshmensis has never been described in any acotylean species. This apparent cell mass does not form a clear organ, but is limited by a characteristic disposition of muscular fibres. We hypothesise that this structure is involved in the structural functioning of the male copulatory organ, providing both hydrostatic support and high plasticity in the rearrangement of the cell mass when the ejaculatory duct and stylet are extended. We will consider this character of specific level until further evidence is gathered.

In 1983, Faubel had already stated the lack of uniformity within the family Notoplanidae. For that reason, he created the family Pleioplanidae, assembled the Notoplanidae species into two families based on the structure of the tubular chambered prostatic vesicle and proposed that it could be considered an apomorphy. Later, Bulnes et al. (2009) described two new Pleioplana species and observed that the number of secretory chambers within the prostatic vesicle remains constant within the species. In 2010, Bulnes made some remarks regarding the glandular lining of the prostatic vesicle as well as the relationship of the ejaculatory duct to the prostatic vesicle, created a new genus and proposed an emendation to Faubel's identification

Figure 7. Persica qeshmensis. (A) Holotype; (B) cleared stained paratype specimen ZUTC Platy.1258; (C) cleared stained paratype specimen ZUTC Platy.1262; (D, F, H) sagittal diagrammatic representation of the male reproductive complex through resting position and extended; $(\mathrm{E}, \mathrm{G})$ dorsal diagram male copulatory organ in resting and extended position. Abbreviations: pv, prostatic vesicle; $\mathrm{s}$, stylet, sv, seminal vesicle; $\mathrm{X}-\mathrm{X}^{\prime}$, longitudinal body axis. 
key to the families of Leptoplanoidea. The family Pleioplanidae is characterised by the presence of an ejaculatory duct projecting distally into the prostatic vesicle, a tubular inner lining projecting backwards filling out the whole lumen and not directly attached to the ejaculatory duct. Persica qeshmensis possesses an interpolated prostatic vesicle of atomata-type, where the ejaculatory duct projects deeply into the vesicle's lumen, and the tubular glandular projections fill two thirds of the prostatic cavity and are not attached to the muscular ejaculatory duct. Based on these characters, the genus Persica belongs in the family Pleioplanidae. The genus Izmira Bulnes, 2010 is the only other pleioplanid genus, apart from the new Persica, lacking Lang's vesicle. The genus Izmira possesses tentacular eyes while the cerebral eyes are absent, lacks tentacles, has a penis rod and has a vagina bulbosa. Persica differs from the genus Izmira because of the presence of tentacular and cerebral eyes, small tentacles, a long and slender stylet and the absence of a vagina bulbosa.

The arrangement of the male copulatory complex, directed backwards, not aligned with the main longitudinal body axis, but being coiled or folded (Figure 7E), was also observed in Izmira turkeyi (Bulnes, 2010). In resting position, the male copulatory complex of $P$. qeshmensis lies folded in the body. During the extension, the male atrium turns inside out first, then the penis sheath and, when completely extended, it stretches out, now parallel to the major body axis, and extends over a distance two times the length of the stylet (Figure 7D-H). Faubel (1983, p. 23) suggested that the penis sheath is only a circular protrusion of the male atrium, and hypothesised it would serve as support for the stylet. The uniformity of this structure suggests, indeed, that the penis sheath is a fold of the male atrium (Figure 4A-C), developed to accommodate the elongated cuticularised copulatory organ in the flattened body. While the sperm is stored in the spermiducal bulbs and the prostatic secretions are provided by the extra-vesicular glands (Figure 4B, D); the highly muscularised seminal vesicle, the prostatic vesicle and the ejaculatory duct act as pumping organs, pushing the secretions up to the distal end of the extended stylet.

The diagnostic characters of Persica qeshmensis mentioned above justify the creation of the new species and the monotypic genus Persica, within the Pleioplanidae.

\section{Funding}

The authors are sincerely grateful to the Iranian National Institute for Oceanography and Atmospheric Science (INIOAS), which generously provided us sufficient budget (Project grant no. 389-D-05-01) and instruments. This study was partly financed by the Research Office of the University of Tehran.

This contribution was partially funded by the INIOAS, University of Tehran, Consejo Nacional de Investigaciones Científicas y Técnicas and the Universidad Nacional del Sur.

\section{References}

Bulnes VN. 2010. Five new Polycladida (Platyhelminthes: acotylea) species from the Aegean Sea with remarks on the prostatic structures. J Nat Hist. 44:515-544.

Bulnes VN, Kalkan E, Karhan SÜ. 2009. Two new Pleioplana species (Platyhelminthes, Polycladida, Acotylea) from Turkey. J Nat Hist. 43:2273-2281. 
Faubel A. 1983. The Polycladida, Turbellaria. Proposal and establishment of a new system. Part I. The Acotylea. Mitteilungen Hamburgisches Zoologisches Museum und Institut. 80:17-121.

Faubel A. 1984. The Polycladida, Turbellaria. Proposal and establishment of a new system. Part II. The Cotylea. Mitteilungen Hamburgisches Zoologisches Museum und Institut. 81:189-259.

Gammoudi M, Tekaya S, Noreña C. 2009. Contribution to the knowledge of Acotylean Polyclads (Platyhelminthes, Polycladida) from Tunisian Coasts. Zootaxa. 2195:43-60.

Gertraud R. 1999. Histological Techniques: whole mount preparations [Internet]. Bethesda: National Institute of Diabetes and Digestive and Kidney Diseases National Institutes of Health. [cited 2012 May 17]. Available from: http://mammary.nih.gov/tools/histological/ Histology/index.html

Kato K. 1937. Three Polyclads from northern Japan. Annot Zool Jap. 16:35-38.

Lang A. 1884. Die Polycladen (Seeplanarien) des Golfes von Neapel und der angrenzenden Meeresabschnitte. Fauna und Flora des Golfes von Neapel monograph 11. Leipzig: Verlag von W. Engelman; p. 688.

Marcus E. 1947. Turbellarios marinhos do Brasil. Bol Fac Fil Ci Letr Univ São Paulo Zool. 12:99-215.

Müller OF. 1776. Zoologiae danicae prodromus, seu animalium Daniae et Norvegiae indigenarum characteres, nomina et synonyma imprimmis popularium. Havniae; $282 \mathrm{p}$.

Newman LJ, Cannon LRG. 1995. The importance of the fixation of colour,pattern and form in tropical Pseudocerotidae (Platyhelminthes, Polycladida). Hydrobiologia. 305:141-143.

Prudhoe S. 1985. A monograph on polyclad Turbellaria. London: British Museum (Natural History); Oxford University Press; p. 259. 